\title{
Impacts of Ultrasonic Waves on Seeds: A Mini-Review
}

\author{
Meisam Nazari ${ }^{1,2 *}$ and Mohammad Eteghadipour ${ }^{3}$ \\ ${ }^{1}$ Department of Agricultural Sciences, Georg-August University of Gottingen, Germany \\ ${ }^{2}$ Department of Organic Agriculture, University of Kassel, Germany \\ ${ }^{3}$ Department of Water and Soil, Shahrood University of Technology, Iran
}

Submission: April 04, 2017; Published: April 28, 2017

*Corresponding author: Meisam Nazari, Department of Agricultural Sciences, Georg-August University of Gottingen, Busgenweg 5, 37077 Gottingen, Germany, Tel: 0049-15772905766; Email: meisam.nazari@stud.uni-goettingen.de

\begin{abstract}
Seeds are essential in rebuilding the production capacity of a crop, maintaining the germplasm, and improving species diversity. The ultrasound technology has been successfully used in many mass transfer processes in food, such as in drying, extraction, osmotic dehydration, desalting and hydration. However, during the recent years, ultrasonic waves have also vastly been applied as an efficient technique for breaking seed dormancy and improving the germination characteristics. This mini-review aimed to investigate the impacts of ultrasonic waves on seed germination percentage and speed of the different species. As the result of this mini-review, the ultrasonic waves positively affect the germination percentage in all the species except one case. However, the germination speed in all the species increases through application of the ultrasounds. The reasons for the positive effects of the ultrasounds on the seeds are also discussed.
\end{abstract}

\section{Introduction}

Seeds are essential in rebuilding the production capacity of a crop, maintaining the germplasm, and improving species diversity. On the one hand, seed germination is the vital period of plant establishment [1], and on the other hand, rapid germination and seedling emergence are critical factors for successful plant establishment [2]. If plants achieve rapid germination and establishment, then the seedlings are able better to survive different environmental stresses [3]. Some different mechanisms (called dormancy) are used by plants to postpone germination and to protect the seeds until the favorable conditions for seedling are provided. Seed dormancy is defined as the ways of hindering germination for an intact viable seed. Some seeds, especially those which are produced in natural conditions, show different levels of seed dormancy. Dormancy breaking and germination stimulation are important for proliferation and early production of important plants [4]. Different methods have been applied to overcome the seed dormancy such as regulatory hormones [5], salinity, temperature, and humidity [6], light and seed scarification, seed stratification [7] and fertilizers [8-9]. Beside technology, development of new techniques is suggested for breaking the seed dormancy such as magnetic water [10] and Nano-compounds [11]. Recently, use of ultrasonic waves as a safe, easy, and time-saving technique for seed dormancy breaking has attracted the researcher's attention [4,12-14].
Ultrasonic waves are mechanical waves of a frequency higher than $20000 \mathrm{~Hz}$, which are not detectable by human's audiation system. The ultrasound technology has been successfully used in many mass transfer processes in food, such as in drying, extraction, osmotic dehydration, desalting and hydration [15]. However, during the recent years, ultrasonic waves have also vastly been applied as an efficient technique for breaking seed dormancy and improving the germination characteristics. The mechanisms of action of the ultrasound on seeds have also been manifested during the recent years more clearly. Despite the publication of many outstanding articles about the positive effects of ultrasonic waves on seed germination characteristics, no review has so far been accomplished on this interesting and important subject. This paper aims to investigate the available articles published on the effects of ultrasound on seeds. The mechanisms of action of ultrasonic waves on seeds are also explored here.

\section{Germination Percentage}

Seed germination is a very important stage of the plant life. Use of ultrasound as a promising technique for breaking seed dormancy and increasing the germination percentage has recently been highlighted by the researcher's. In a research on the effect of ultrasonic waves on pea (Pisumsativum), 
ultrasound application resulted in a $13.1 \%$ increase in the seed germination compared to the control treatment [16]. In another experiment on four crop specieschickpea (Cicer arietinum), wheat (Triticumaestivum), pepper (Capsiumannuum) and watermelon (Citrullus vulgaris) [17], investigated the effect of sonication on the seeds' germination percentage. The germination percentage of chickpea, wheat and watermelon was increased by $36 \%, 2 \%$ and $2 \%$, respectively, in comparison with the control. But the seeds of pepper responded to ultrasound negatively and the germination percentage decreased by $19 \%$. It seems that exposure of some species' seeds to ultrasound could decreases the germination percentage. In this respect, It showed that exposure of fennel (Foeniculum vulgare) seeds to ultrasonic waves leads to a $30.5 \%$ decrease in the germination percentage. In an in vitro experiment performed by Nazari [4], it was indicated which ultrasound enhances snail medick (Medicagoscutellata (L.) Mill) seed germination by $63.3 \%$ compared to the control. In a similar experiment, it was shown that the seed germination of three important medicinal species respond to sonication positively; as the seed germination of big saltbush (Atriplexlentiformis), cumin (Cuminumcyminum) and caper beans (Zygophyllumeurypterum) was increased up to 28 $\%, 36 \%$ and $35.7 \%$, respectively, compared to the control [1]. In another study on the effects of ultrasonic waves on sunflower (Helianthus annuus L.) seeds, the germination was increased by the maximum 43.38 \% [18]. Further, Risca and Fartais 2009

Table 1: Effect of ultrasonic waves on seed germination percentage of the reviewed species.

\begin{tabular}{|c|c|c|c|}
\hline \multirow[t]{2}{*}{ Author (s) } & \multirow[t]{2}{*}{ Species } & \multicolumn{2}{|c|}{ Germination \% } \\
\hline & & Control & Ultrasound \\
\hline Chiu \& Sung [16] & Pisum Sativum & 85 & $98.1^{*}$ \\
\hline Goussous et al. [17] & Cicer arietinum & 61 & $97^{*}$ \\
\hline Goussous et al. [17] & Triticum aestivum & 98 & $100^{*}$ \\
\hline Goussous et al. [17] & Citrullus vulgaris & 98 & $100^{*}$ \\
\hline Goussous et al. [17] & Capsium аппиит & 72 & $53^{*}$ \\
\hline Fateh et al. [10] & Foeniculum vulgare & 90 & $59.5^{*}$ \\
\hline Nazari et al. [4] & Medicago scutellata (L.) Mill & 33.3 & $96.6^{* *}$ \\
\hline Sharififar et al. [1] & Atriplex lentiformis & 40 & $68^{* *}$ \\
\hline Sharififar et al. [1] & Cuminum cyminum & 44 & $80^{* *}$ \\
\hline Sharififar et al. [1] & Zygophyllum eurypterum & 37.5 & $73.3^{* *}$ \\
\hline Machikowa et al. [18] & Helianthus annuus $L$. & 54.6 & $98^{*}$ \\
\hline Machikowa et al. [18] & Picea abies (L.) Karsten & 46 & $68^{*}$ \\
\hline Aladjadjiyan [19] & Triticum aestivum & 90 & $94^{*}$ \\
\hline Aladjadjiyan [19] & Lens culinaris, Med. & 92 & $98^{*}$ \\
\hline Liu et al. [14] & Festuca arundinacea & 38.7 & $78.7^{*}$ \\
\hline Liu et al. [14] & Psathyrostaehys juncea Nevski & 39.3 & $89.3^{*}$ \\
\hline Toth [20] & Lotus corniculatus L. & 77.1 & $86.1^{*}$ \\
\hline Wang et al. [22] & Panicum virgatum $L$. & 66.9 & $90.1^{*}$ \\
\hline Yaldagard et al. [26] & Hordeum vulgare $L$. & 93 & $99^{*}$ \\
\hline Miyoshi \& Mii [21] & Calanthe discolor & 10 & $60^{*}$ \\
\hline
\end{tabular}




\section{Germination speed}

Germination speed is a very important factor in proper establishment of plants in natural habitats or in the field. A quickly germinating seed can use the available nutrients and water more timely and more efficiently [23]. Many techniques are available for increasing the germination speed of different species. Acid sulfuric and cold stratification are the two widely used methods. Ultrasound, as a new and easy-to-use technique, has recently attracted the researchers' attention. In a research on pea (Pisumsativum) [16], indicated that treating the seeds with ultrasonic waves increases the germination speed by 93 $\%$. In another study, it was shown that ultrasound enhances the germination speed of chickpea, wheat, watermelon and pepper seeds up to $20,36,16$ and $1.8 \%$, respectively [17]. In a recently published article [15], revealed which sonication can increase the germination speed of mung bean (Vigna radiata) seeds by $25 \%$.Further, in a study on the effects of sonication on barley seeds, the germination speed increased by $45 \%$ significantly [12]. To sum up, in all the species investigated so far, sonication significantly increases the seed germination. However, it should be clear that how ultrasonic waves improve the germination speed as well as the germination percentage. A summary of the findings about the effects of ultrasounds on seed germination speed of the mentioned plant species has been provided (Table 2).

Table 2: Effect of ultrasonic waves on seed germination speed of the reviewed species.

\begin{tabular}{|c|c|c|}
\hline Author (s) & Species & Increase in germination speed (\%) \\
\hline Chiu \& Sung [16] & Pisum Sativum & $23^{*}$ \\
\hline Goussous et al. [17] & Cicer arietinum & $20^{*}$ \\
\hline Goussous et al. [17] & Triticum aestivum & $43^{*}$ \\
\hline Goussous et al. [17] & Citrullus vulgaris & $16^{*}$ \\
\hline Goussous et al. [17] & Capsium annuum & $1.8^{*}$ \\
\hline Dutheil et al. [31] & Hordeum vulgare L. & $20^{*}$ \\
\hline Claudio Miano et al. [15] & Vigna radiata & $25^{*}$ \\
\hline Yaldagard et al. [26] & Hordeum vulgare L. & $45^{*}$ \\
\hline
\end{tabular}

\section{Mechanisms of Action}

The impacts of ultrasonic waves on seed germination of the different species have so far been investigated. However, there has been scattered views in terms of the action mechanisms of ultrasounds on seeds.

Ultrasounds are mechanical waves of a frequency higher than $20000 \mathrm{~Hz}$. Water is used as a medium for treating the seeds by ultrasounds [4]. Seeds of the desired species are placed in to an ultrasonic wave emitting apparatus containing water [1].

Water uptake and oxygen availability are the essentials of seed germination. Therefore, ultrasonic waves should alter the seed's characteristics through which more water and oxygen are available. In water, ultrasonic waves lead to cavitation [2426], Cavitation is a phenomenon by which micro-bubbles are created in water. The cavitation created by the ultrasound causes a mechanical pressure on the seeds [26,27]. This mechanical pressure then leads to the cell wall fluidity [26], and to the creation of micro-pores and micro-cracks on the cell wall [28]. It has also been shown that the porosity of mung bean seeds increase by ultrasonic waves [15]. The creation of micro-pores and micro-cracks caused by sonication means that the seeds are more permeable to water and oxygen entry [15]. Researchers have indicated that exposure of the seeds to the ultrasound enhances hydration $[29,30,26,15]$. It seems that increase in hydration of the seeds treated with ultrasonic waves results in an increase in enzymatic activities especially alpha-amylase $[1,15,26]$. Consequently, the starch hydrolysis is enhanced followed by increase in the seed germination percentage and speed $[1,26]$. A schematic representation of the processes by which ultrasonic waves affect the seeds has been provided (Figure 1) [31].

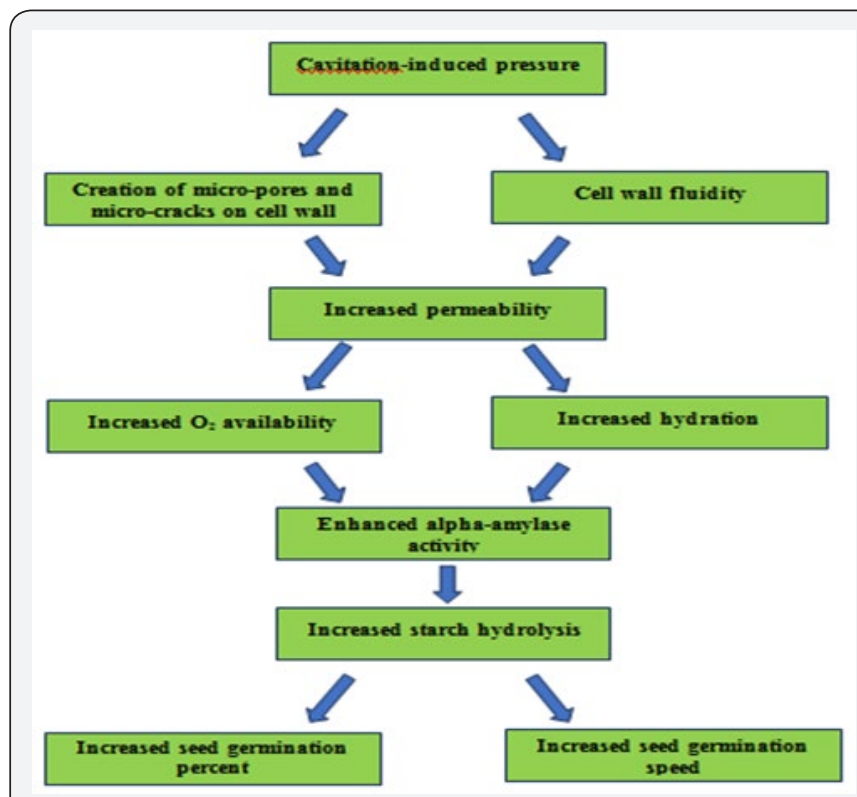

Figure 1: Schematic representation of the processes by which ultrasounds affect seeds..

\section{Conclusion}

In this mini-review, the effects of ultrasonic waves on seed germination percentage and speed of the different species were 
evaluated. Moreover, the mechanisms by which the ultrasounds impact the seeds were investigated. As it was investigated, in all the species (except two of them), the ultrasound can enhance seed germination percentage. It also can increase seed germination speed in all the species surveyed. About the action mechanisms, it is concluded that the ultrasounds impose a mechanical pressure on the seed's cell wall. This pressure increases the seed's porosity, and consequently rises the seed's permeability to oxygen and water. After this, the alpha-amylase activity inside the seed increases which leads to increased hydrolysis of the starch. Finally, the germination percentage and speed are enhanced. At the end, the authors would like to advise the investigation of more other species affected by ultrasonic waves.

\section{Advantages and Disadvantages of the Method}

Ultrasound, as a seed priming technique, seems to be applied easier compared to the other methods like sand scarification, acid scarification, and other available methods. Moreover, the ultrasounds only impose mechanical pressure on seeds to break the dormancy; therefore, no chemicals would contaminate the seeds. The disadvantage of application of ultrasonic waves in seed industries is the small size of the available apparatuses. A scaling-up is required in order to manufacture huge ultrasoundemitting sets specialized for seed priming purposes.

\section{Acknowledgement}

The authors would like to thank the library experts of the Georg-August University of Gottingen and University of Kassel for their cooperation in providing the related books and articles.

\section{References}

1. Sharififar A, Nazari M, Asghari HR (2015) Effect of ultrasonic waves on seed germination of Atriplexlentiformis, Cuminumcyminum, and Zygophyllum eurypterum. Journal of Applied Research on Medicinal and Aromatic Plants 2(3) : 102-104

2. Harris D, Joshi A, Khan PA, Gothkar P, Sodhi PS (1999) On-farm seed priming in semi-arid agriculture: development and evaluation in maize, rice and chickpea in India using participatory methods. Experimental Agriculture 35: 15-29.

3. Klein JD, Mufradi I, Cohen S, Hebbe Y, Asido S, et al. (2002) Establishment of wheat seedlings after early sowing and germination in an arid Mediterranean environment. Agronomy Journal 94: 585-593.

4. Nazari M, Sharififar A, Asghari HR (2014) Medicago scutellata seed dormancy breaking by ultrasonic waves. Plant Breeding and Seed Science 69(1): 15-24.

5. Sozi G, Chiesa AO (1995) Improvement of caper (Capparisspinosa L.) seed germination by breaking seed coat-induced dormancy. Scientica Horticulture 62(4): 255-261.

6. Bradbeer JW (1998) Seed Dormancy and Germination. Chapman and Hall, New York, USA, pp. 38-54.

7. Lindig CR, Lara-Cabrera S (2004) Effect of scarification and growing media on seed germination of Crotalaria pumila (Ort.). Seed Science and Technology 32(1): 231-234.

8. Ramteke AA, Shirgave PD (2012) Study the effect of common fertilizers on plant growth parameters of some vegetable plants. Journal of
Natural Product and Plant Resources 2(2): 328-333.

9. Ramteke AA, Narwade ML, Gurav AB, Chavan SP, Wandre AG (2013) Study of germination effect of fertilizers like urea NPK and biozyme on some vegetable plants. Der Chemica Sinica 4(3): 22-26.

10. Fateh E, Noroozi H, Farbod M, Gerami F (2012) Assessment of fennel (Foeniculum vulgare) seed germination characteristics as influenced by ultrasonic waves and magnetic water. European Journal of Experimental Biology 2(3): 662-666.

11. Azimi MS, Daneshian J, Sayfzadeh S, Zare S (2013) Evaluation of amino acid and salicylic acid application on yield and growth of wheat under water deficit. International Journal of Agriculture and Plant Sciences 5(8): 519-816.

12. Yaldagard M, Mortazavi SA, Tabatabaie F (2008) Influence of ultrasonic stimulation on the germination of barley seed and its alpha-amylase activity. African Journal of Biotechnology 7(14): 2465-2471.

13. Ramteke AA, Meshram UP, Yaul AR (2015) Effect of ultrasonic waves on seed germination of Lycopersicon Esculentum and Anethum Graveolens. International Journal of Chemical and Physical Sciences 4: 333-336.

14. Liu J, Wang Q Karagić D, Liu X, Cui J, et al. (2016) Effects of ultrasonication on increased germination and improved seedling growth of aged grass seeds of tall fescue and Russian wildrye. Scientific Reports Nature 6: 22403.

15. Miano CA, da Costa Pereira J, Castanha N, da Matta Júnior MD, Augusto ED (2016) Enhancing mung bean hydration using the ultrasound technology: description of mechanisms and impact on its germination and main components. Scientific Reports Nature 6: 388996.

16. Ciu KY, Sung JM (2014) Use of ultrasonication to enhance pea seed germination and microbial quality of pea sprouts. International Journal of Food Science and Technology 49: 1699-1706.

17. Goussous SJ, Samarah NH, Alqudah AM, Othman MO (2010) Enhancing seed germination of four crops species using an ultrasonic technique. Experimental Agriculture $46: 231-242$.

18. Machikowa T, Kulrattanarak T, Wonprasaid S (2013) Effects of ultrasonic treatment on germination of synthetic sunflower seeds. International Journal of Biological, Biomolecular, Agricultural Food and Biotechnological Engineering 7(1): 1-3.

19. Aladjadjiyan A (2011) Ultrasonic stimulation of the development of lentils and wheat seedlings. Romanian Journal of Biophysics 21(3) : 179-187.

20. Toth I (2012) The effects of ultrasound exposure on the germination capacity of birds foot trefoil (Lotus corniculatusL.) seeds. Romanian Journal of Biophysics 22(1): 13-20.

21. Miyoshi K, Mii M (1988) Ultrasonic treatment for enhancing seed germination of terrestrial orchid, Calanthediscolor, in a symbiotic culture. Scientia Horticulturae 35: 127-130.

22. Wang Q, Chen G, Yersaiyiti H, Liu Y, Cui J, et al. (2012) Modeling analysis on germination and seedling growth using ultrasound seed pretreatment in switchgrass. PLOS ONE 7(10): e47204.

23. Bort J, Araus JL, Hazzam H, Grando S, Ceccarelli S (1998) Relationships between early vigor, grain yield, leaf structure and stable isotope composition in field grown barley. Plant Physiology and Biochemistry 36: 889-897.

24. Piyasena P, Mohareb E, McKellar RC (2003) Inactivation of microbes using ultrasound: a review. International Journal of Food Microbiology 87(3): 207-216.

25. O'Donnell CP, Tiwari BK, Bourkec P, Cullen PJ (2010) Effect of ultrasonic processing on food enzymes of industrial importance. Trends in Food Science \& Technology 21: 358-367. 
26. Yaldagard M, Mortazavi SA, Tabatabaie F (2008) Application of ultrasonic waves as a priming technique for accelerating and enhancing the germination of barley seed: optimization of method by the Taguchi approach. Journal of Institute of Brewing 114(1): 14-21.

27. Hu A, Zhao S, Liang H, Qiu T, Chen G (2007) Ultrasound assisted supercritical fluid extraction of oil and coixenolide from adlay seed. Ultrasonics Sonochemistry 14: 219-224.

28. Jaime A, da Silva T, Dobra'nszki J (2014) Sonication and ultrasound: impact on plant growth and development. Plant Cell tissue and Organ Culture 117: 131-143.

This work is licensed under Creative Commons Attribution 4.0 License

DOI: $10.19080 /$ ARTOAJ.2017.06.555688
29. Toma M, Vinatoru, Paniwnyk L, Mason TJ (2001) Investigation of the effects of ultrasound on vegetal tissues during solvent extraction. Ultrasonic Sonochemistry 8: 137-142.

30. Jambrak AR, Mason TJ, Paniwnyk L, Lelas V (2007) Accelerated drying of button mushrooms, Brussels sprouts and cauliflower by applying power ultrasound and its rehydration properties. Journal of Food Engineering 81: 88-97.

31. Dutheil E, Tiwari B, Gupta M, Cullen PJ, Brennan C, et al. (2011) Effect of sonication on malting behaviour of barley. ICEF, Athens, Greece.

\section{Your next submission with Juniper Publishers will reach you the below assets}

- Quality Editorial service

- Swift Peer Review

- Reprints availability

- E-prints Service

- Manuscript Podcast for convenient understanding

- Global attainment for your research

- Manuscript accessibility in different formats

( Pdf, E-pub, Full Text, Audio)

- Unceasing customer service

Track the below URL for one-step submission

https://juniperpublishers.com/online-submission.php 